\title{
ОСНОВНЫЕ ХАРАКТЕРИСТИКИ МИРОВОГО РЫНКА ВЫСОКИХ ТЕХНОЛОГИЙ И ЕГО ГЕОГРАФИЧЕСКАЯ СТРУКТУРА НА СОВРЕМЕННОМ ЭТАПЕ ЭКОНОМИЧЕСКОГО РАЗВИТИЯ
}

\section{THE MAIN CHARACTERISTICS \\ AND GEOGRAPHICAL STRUCTURE OF THE WORLD MARKET OF THE HIGH TECHNOLOGIES AT THE CURRENT STAGE OF THE ECONOMIC DEVELOPMENT}

R. Gurkov

Summary. The article discusses the main trends in the world market of high-tech and science-intensive goods and services. The author conducts a comparative analysis of the productivity of high-tech and knowledge-intensive industries indicated by the value added. The sectoral approach to determining the level of manufacturability of industries is based on the methodology of the International Standard Industrial Classification of All Economic Activities (ISIC, Rev. 4). The author concluded that the leadership in the high-tech and mediumtech industries production is transferring to the countries of Asia, while countries of the North America and Western Europe are losing their positions.

Keywords: technology transfer, scientific research, high-tech industry, technologies, Asian countries, innovative economy, trade and economic development.
B международной плоскости вопрос разделения отраслей промышленности в соответствии с уровнем их технологического развития впервые был затронут еще в начале $80-x$ годов XX века и на сегодняшний день не предложено более структурированной альтернативной методологии, чем методология разработанная ОЭСР, в основу которой положен анализ соотношения затрат на исследования и разработки с добавленной стоимостью, формируемой отраслью или валовым выпуском, формируемым этой отраслью[1]. Итогом продолжительной работы вышеупомянутой организации стало создание единого мето-
Гурков Родион Александрович

Аспирант, Всероссийская академия внешней торговли Министерства экономического развития

Российской Федерации; Ведущий советник отдела стран Юго-Восточной Азии и Океании Департамента стран Азии, Африки, Латинской Америки Минпромторга России gurkov_rodion@mail.ru

Аннотация. В статье рассматриваются основные тенденции, протекающие на мировом рынке высокотехнологичных и наукоемких товаров и услуг. Автором проводится сравнительный анализ производительности высокотехнологичных и наукоемких отраслей промышленности в соответствии с показателями добавленной стоимости, формируемой этими отраслями. За основу взят отраслевой подход определения уровня технологичности отраслей промышленности, базирующийся на методологии Международной стандартной отраслевой классификации (МСОК) - International Standard Industrial Classification of All Economic Activities (ISIC, Rev. 4). Проведенный анализ, позволил автору сделать вывод о том, лидерство в производстве продукции и услуг высокотехнологичных и среднетехнологичных отраслей промышленности высокого уровня переходит к странам Азии, а страны североамериканского и западноевропейского континента продолжают утрачивать свои позиции.

Ключевые слова: международный технологический обмен, научно-исследовательская деятельность, высокотехнологичная промышленность, технологии, страны Азии, инновационная экономика, торгово-экономическое развитие.

дического пособия «Руководство по измерению информационного общества» [2].

В настоящее время мировая практика использует два основных подхода определения уровня технологичности отрасли или товара.

«Продуктовый подход» предполагает технологическую градацию промышленной продукции по расходам на ее исследования и разработки при производстве в соотношении к стоимости единицы этой реализованной продукции. В настоящее время при данном под- 
Таблица 1. Показатели объемов производства и доли в мировом ВВП высокотехнологичных и наукоемких отраслей промышленности, 2019 г.

\begin{tabular}{|c|c|c|}
\hline Промышленность & $\begin{array}{l}\text { Добавленная стоимость } \\
\text { (млрд. долл. США) }\end{array}$ & $\begin{array}{l}\text { Доля } \\
\text { мирового ВВП } \\
\text { (\%) }\end{array}$ \\
\hline Общий объем высокотехнологичных и наукоемких отраслей & 9020,7 & 11,1 \\
\hline Высокотехнологичная промышленность & 3241,8 & 4,0 \\
\hline Авиационная промышленность & 243,1 & 0,3 \\
\hline Компьютерные, электронные и оптические изделия & 1185,9 & 1,5 \\
\hline Фармацевтическая промышленность & 698,7 & 0,8 \\
\hline Научно-исследовательская деятельность & 652,5 & 0,8 \\
\hline Программное обеспечение & 461,6 & 0,6 \\
\hline $\begin{array}{l}\text { Среднетехнологичная промышленность } \\
\text { высокого уровня }\end{array}$ & 5778,9 & 7,1 \\
\hline Химические вещества, за исключением фармацевтических препаратов & 1026,5 & 1,3 \\
\hline Электротехническое оборудование & 655,7 & 0,8 \\
\hline ИТ-услуги & 1621,8 & 2,0 \\
\hline Прочие машины и оборудование & 1195,2 & 1,5 \\
\hline Автомобильный транспорт & 1109,7 & 1,4 \\
\hline Железные дороги и военная техника & 119,9 & 0,1 \\
\hline Оружие & 50,1 & 0,1 \\
\hline
\end{tabular}

Источник: рассчитано автором на основе [5].

ходе используется четвертая редакция Стандартной международной торговой классификации «(Standard International Trade Classification, SITC)» [3].

«Отраслевой подход» опирается на классификацию отраслей промышленности в зависимости от интенсивности осуществления затрат на научно-исследовательские и опытно-конструкторские работы. При данном подходе используется четвертая модернизированная версия Международной стандартной отраслевой классификации (МСОК) - International Standard Industrial Classification of All Economic Activities (ISIC, Rev. 4)[4], которая впервые расширила анализ интенсивности затрат на НИОКР на непроизводственные отрасли, которые включают широкий спектр услуг.

Для дальнейшего анализа тенденций на мировом рынке высокотехнологичных и наукоемких товаров и услуг, нами будет взят за основу отраслевой подход.

Согласно данным Международной стандартной отраслевой классификации к высокотехнологичным отраслям промышленности относятся: авиационная промышленность, компьютерная, электронная и оптическая продукция, фармацевтическая промышленность, научно-исследовательская деятельность, создание программного обеспечения.

К среднетехнологичным отраслям промышленности высокого уровня относятся: производство химических веществ (за исключением фармацевтических препаратов), электротехническое оборудование, информационно-технологические услуги (ИТ), машины, оборудование, автотранспортные средства, железнодорожный и другой транспорт, а также оружие. В этих отраслях наблюдается более низкий, но все же существенный уровень технологичности. (Таблица 1).

Совокупный объем добавленной стоимости высокотехнологичных и наукоемких отраслей промышленности в 2019 г. составил чуть более 9 трлн. долл. США, что составляет 11,1\% мирового ВВП. При этом на долю производства среднетехнологичных отраслей промышленности высокого уровня приходится 64\% мирового объема производства или 7\% мирового ВВП. Доля производства высокотехнологичных отраслей практически в два раза ниже (36\% общего объема высокотехнологичной и наукоемкой продукции и услуг) и составляет 4\% мирового ВВП.

Согласно имеющимся статистическим данным, определилось пять основных центров - производителей высокотехнологичной и наукоемкой продукции: США, Европейский Союз (ЕС), Китай, Япония и группа азиатских стран (другие страны Азии) - Республика Корея, Республика Индия, Республика Индонезия, Малайзия, Республика Филиппины, Республика Сингапур, Королевство Таиланд и Социалистическая Республика Вьетнам (Таблица 2).

Как в США, так и в ЕС доля производства высокотехнологичных и наукоемких отраслей в их внутреннем ВВП составляет, как и в среднем по миру $11 \%$. Доля Ки- 
Таблица. 2. Добавленная стоимость производства высокотехнологичных и наукоемких отраслей промышленности по странам и регионам 2004-2019 гг., млрд. долл. США

\begin{tabular}{|l|l|l|l|l|l|l|l|}
\hline Страны & $\mathbf{2 0 0 4}$ & $\mathbf{2 0 0 9}$ & $\mathbf{2 0 1 5}$ & $\mathbf{2 0 1 6}$ & $\mathbf{2 0 1 7}$ & $\mathbf{2 0 1 8}$ & $\mathbf{2 0 1 9}$ \\
\hline Мир & 3876,3 & 6003,7 & 7679,8 & 7545,2 & 7779,1 & 8277,1 & 9020,7 \\
\hline США & 1173,6 & 1455,7 & 1803,8 & 1913,5 & 2003,8 & 2112,6 & 2296,4 \\
\hline ЕС & 1127,7 & 1761,8 & 1821,4 & 1675,7 & 1706,8 & 1757,7 & 1928,5 \\
\hline Азия & 1160,8 & 1912,4 & 2996,0 & 3037,6 & 3179,5 & 3438,5 & 3798,9 \\
\hline Китай & 257,5 & 695,4 & 1574,0 & 1644,5 & 1697,6 & 1905,8 & 2184,4 \\
\hline Индия & 34,4 & 82,2 & 147,2 & 161,2 & 169,1 & 190,8 & 209,2 \\
\hline Индонезия & 18,5 & 34,7 & 55,5 & 52,5 & 54,9 & 58,6 & 58,8 \\
\hline Япония & 627,4 & 740,7 & 668,0 & 634,3 & 710,7 & 672,0 & 703,8 \\
\hline Малайзия & 16,8 & 25,1 & 35,1 & 34,2 & 32,9 & 35,5 & 39,9 \\
\hline Филиппины & 5,2 & 8,9 & 12,7 & 13,6 & 14,8 & 15,4 & 15,0 \\
\hline Сингапур & 17,3 & 28,8 & 45,8 & 44,4 & 45,5 & 52,7 & 57,5 \\
\hline Южная Корея & 101,3 & 163,0 & 259,6 & 255,7 & 249,0 & 279,9 & 294,3 \\
\hline Таиланд & 15,6 & 32,2 & 34,4 & 33,8 & 34,4 & 35,5 & 38,9 \\
\hline Вьетнам & 1,7 & 5,4 & 21,8 & 20,2 & 23,2 & 28,8 & 30,6 \\
\hline
\end{tabular}

Источник: составлено автором на основе [5]

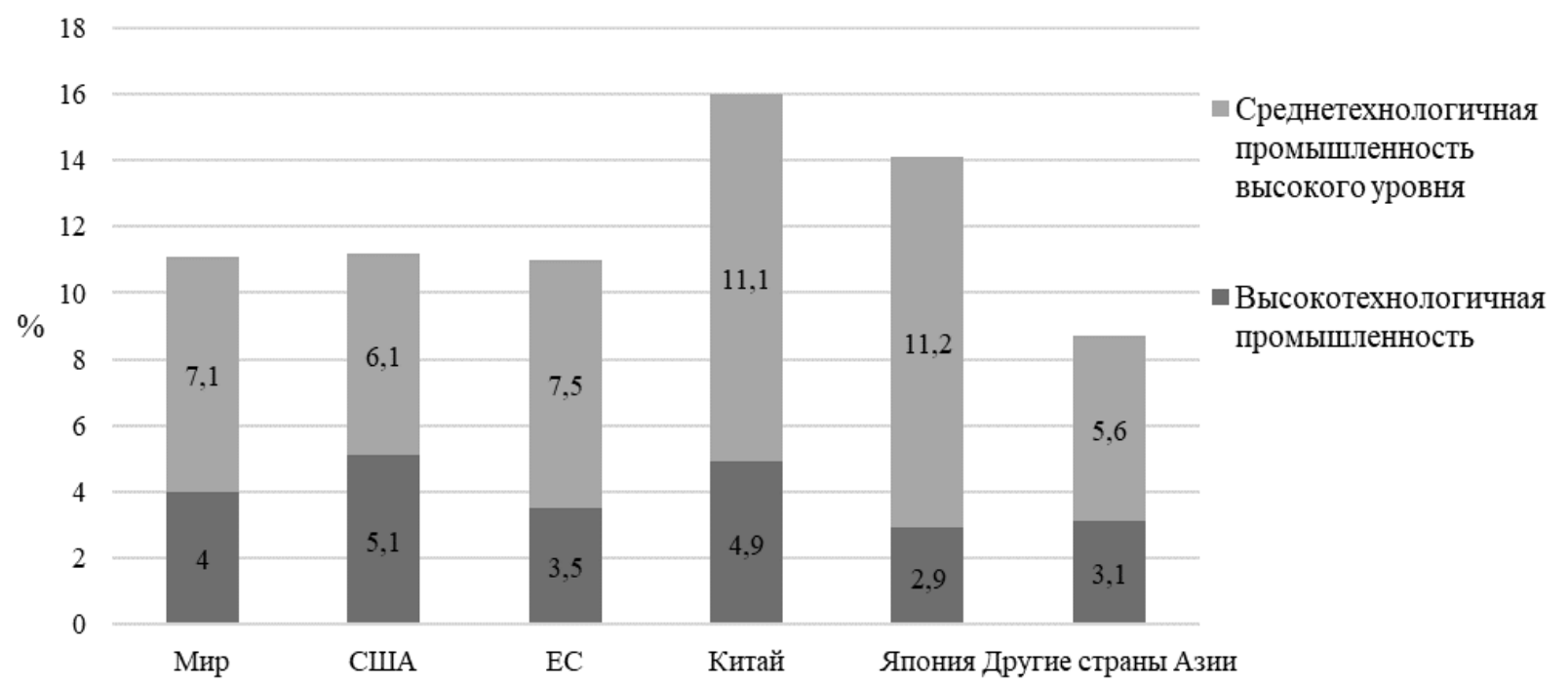

Рис. 1. Доля производства высокотехнологичных и наукоемких отрасли промышленности в ВВП отдельных стран и регионов, 2019 г.

Источник: рассчитано автором на основе [6].

тая и Японии существенно превышает среднемировые показатели за счет более высокого объема выпуска продукции среднетехнологичных отраслей промышленности высокого уровня. Совокупная доля производства высокотехнологичных и наукоемких отраслей промышленности других стран Азии в 2019 г. составила 8,7\%, с преобладающей доля среднетехнологичных отраслей высокого уровня. Стоит также отметить, что доля выпуска высокотехнологичных отраслей других стран Азии сопоставима с аналогичными показателями Японии и стран ЕС (Рисунок 1).
С 2004 г. мировой объем добавленной стоимости производства высокотехнологичных и наукоемких отраслей промышленности вырос в 2,3 раза (с 3,8 трлн. долл. США в 2004 г. до 9,0 трлн. долл. США в 2019 г.), что обусловлено как ростом цен, так и количественным ростом производства.

Рассматривая тенденции, протекающие в высокотехнологичных отраслях промышленности, на протяжении последних двух десятилетий США остаются крупнейшим в мире (более $30 \%)$ производителем про- 


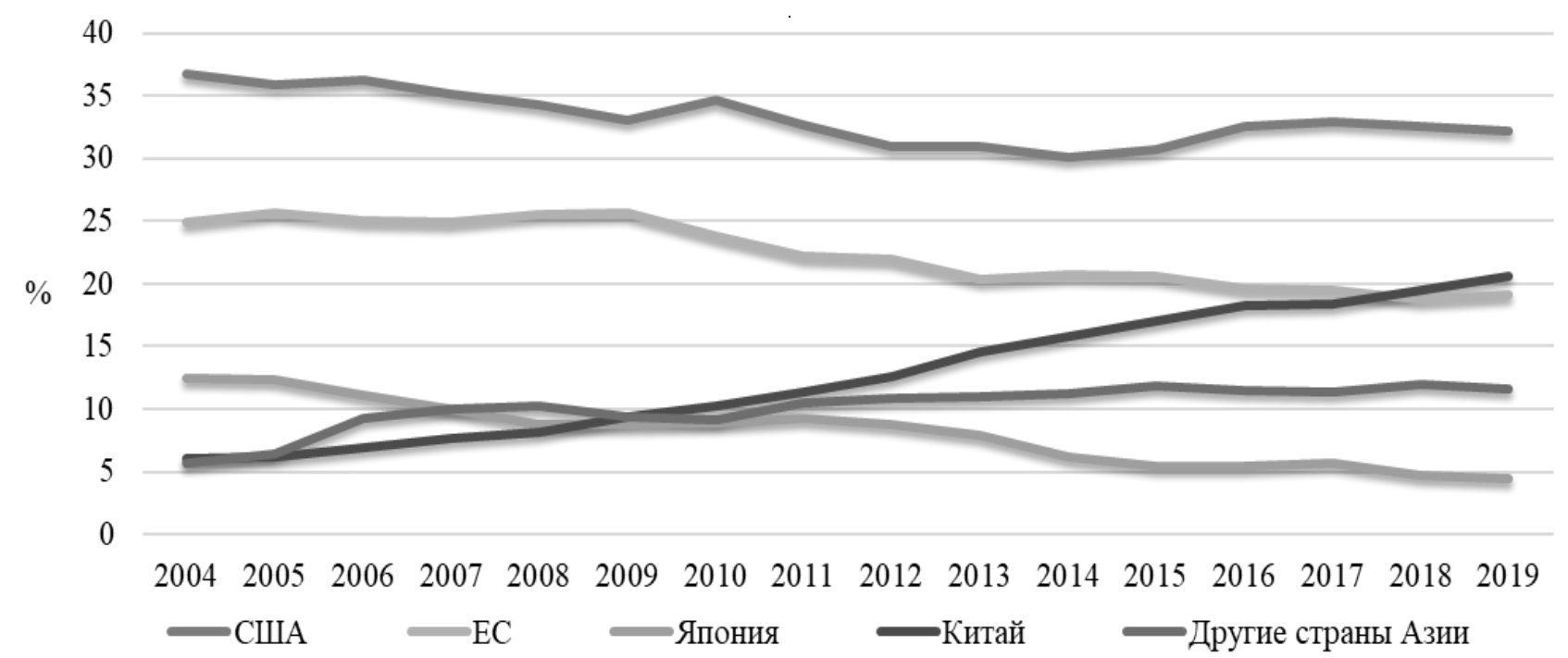

Рис. 2. Доля участия отдельных стран и регионов в создании добавленной стоимости производства продукции и услуг высокотехнологичной промышленности 2004-2019 гг. (\%)

Источник: рассчитано автором на основе [5].

Научно-исследовательская деятельность

Компьютерные, электронные и оптические изделия

Авиационная промышленность
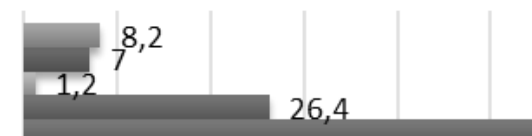

Программное обеспечение

Фармацевтика

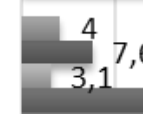

7,6
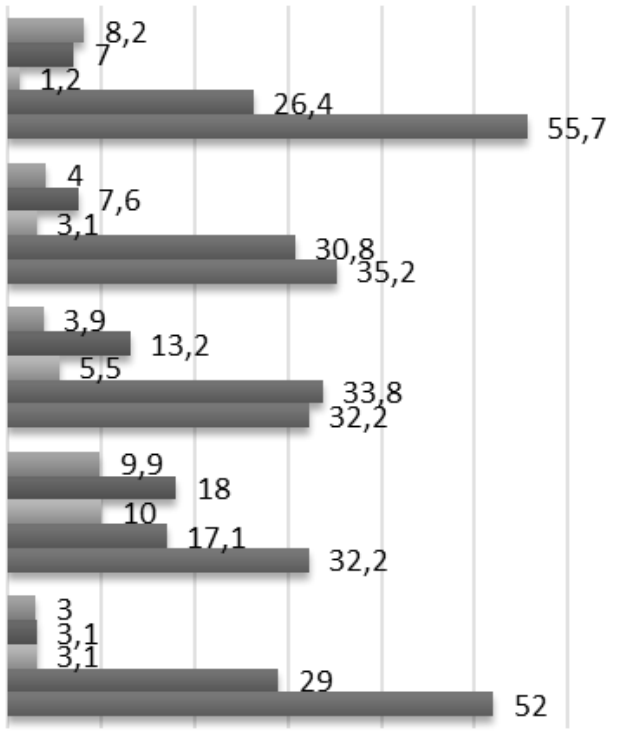

$\begin{array}{llllll}0 & 10 & 20 & 30 & 40 & \begin{array}{l}50 \\ \%\end{array}\end{array}$

$60 \quad 70$

$80 \quad 90 \quad 100$

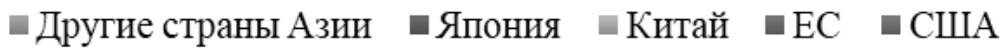

Рис. 3. Доля участия отдельных стран и регионов в создании добавленной стоимости мирового производства высокотехнологичных отраслей промышленности в 2004 г. (\%)

Источник: рассчитано автором на основе [5].

дукции данного сегмента -1,04 трлн. долл. США (Рисунок 2). На доли Китая и ЕС приходится по 20\% мирового объема добавленной стоимости выпуска продукции высокотехнологичных отраслей (669,4 млрд. долл. США и 619,4 млрд. долл. США соответственно.
Стоит отметить что, за последнее десятилетие Китай превратился в крупного производителя продукции и услуг высокотехнологичных отраслей промышленности, и его доля в мировом производстве постоянно растет, в то время как объемы добавленной стоимости 


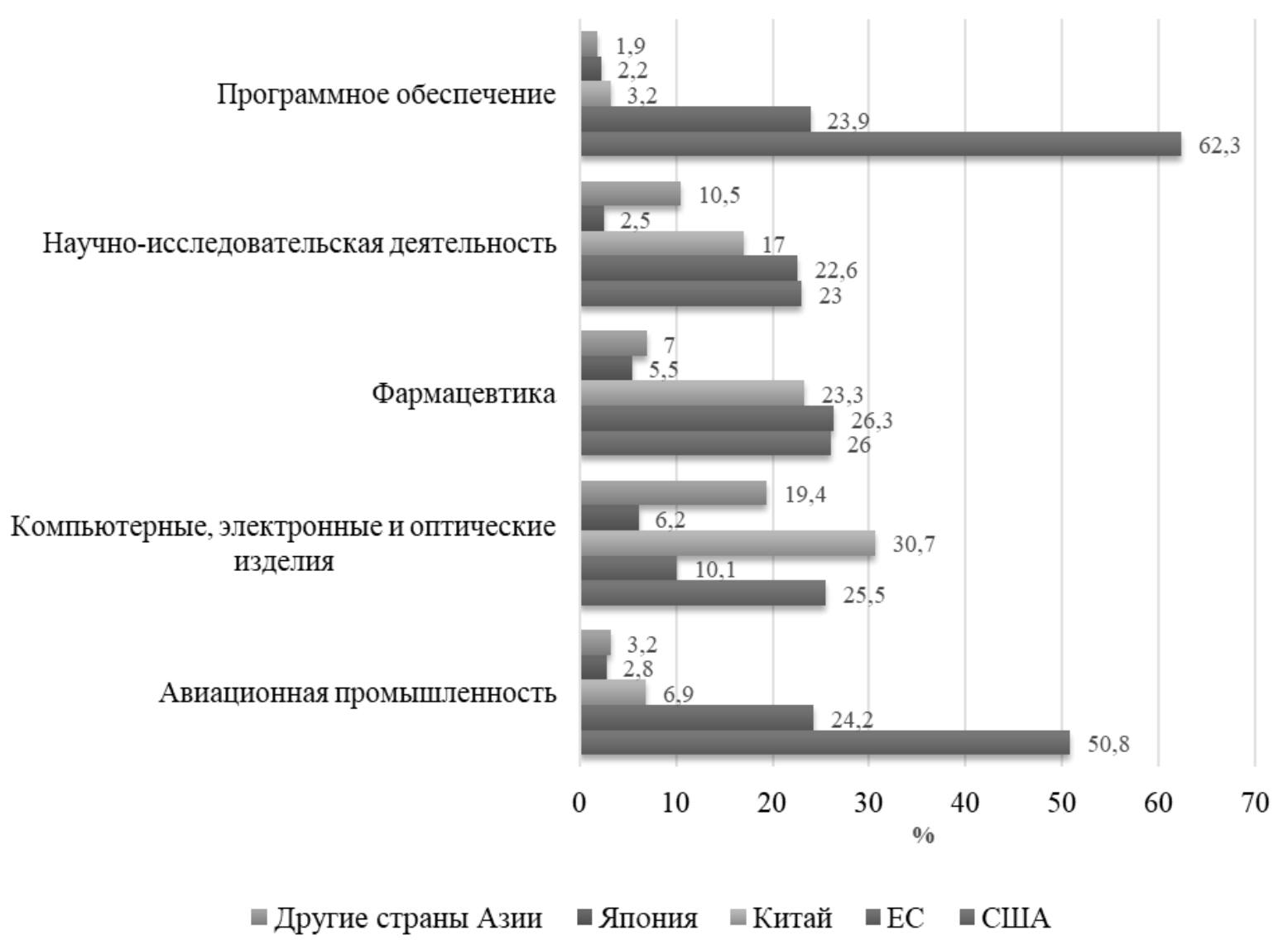

Рис. 4. Доля участия отдельных стран и регионов в создании добавленной стоимости мирового производства высокотехнологичных отраслей промышленности в 2019 г. (\%)

Источник: рассчитано автором на основе [5].

производства Японии и страна ЕС замедлились, что привело к снижению их позиций на мировом рынке высоких технологий.

Совокупный объем добавленной стоимости производства продукции высокотехнологичных отраслей других стран Азии варьируется в диапазоне 8-13\% мирового выпуска и остается стабильным.

Большинство производственных процессов высокотехнологичных отраслей промышленности подвержены процессу глобализации, в которые вовлекаются сложные цепочки добавленной стоимости, охватывающие все большее количество стран. Глобальные цепочки добавленной стоимости (ГЦДС) состоят из широкого спектра различных видов деятельности, начиная от создания концепции и заканчивая итоговой формой готового продукта или спектра предоставляемой услуги. ГЦДС предоставляют возможность всем странам мира, обладающим сравнительными преимуществами, участвовать в производстве, специализируясь на отдельных его сегментах, а не на выпуске всего продукта целиком.
По состоянию на конец 2019 года США являются крупнейшим в мире производителем товаров и услуг высокотехнологичных отраслей и занимают лидирующие позиции в авиационной промышленности - 50,8\% (-1,2\% в сравнении с показателем доля 2004 г.) с объемом производства 123,4 млрд. долл. США и разработке программного обеспечения - 62,3\% (+6,6\% показателя 2004 г.) с объемом производства 287,3 млрд. долл. США (Рисунок 3, Рисунок 4).

Значительную роль в сфере высоких технологий США занимает сфера наукоемких услуг. Однако доля производства добавленной стоимости снизилась в сравнении с показателями 2004 г. (сокращение составило 12,2\%) и в настоящее время на нее приходится 23\% мирового объема производства научно-исследовательских услуг - 149,7 млрд. долл. США.

Также США являются одним из лидеров в производстве фармацевтической и компьютерной, электронной и оптической продукции. В фармацевтической промышленности США разделяют лидерство с ЕС - 26\% и $26,3 \%$ соответственно, или 181,8 млрд. долл. США 
и 183,5 млрд. долл. США. В этой отрасли также произошло сокращение доля производства в сравнении с показателем 2004 г. (-6,2\%).

В компьютерной, электронной и оптической промышленности США являются вторым по величине производителем в мире - 25,5\% (302,2 млрд. долл. США), уступая Китаю с долей - 30,7\% (364,2 млрд. долл. США).

Китай и ЕС являются вторыми по величине производителями товаров и наукоемких услуг высокотехнологичных отраслей промышленности с ростом доли участия в создании добавленной стоимости мирового производства Китая и снижением доли ЕС. Китай сумел существенно нарастить свои позиции с 6\% (92,1 млрд. долл. США) в 2004 г. до 20,6\% (669,4 млрд. долл. США) в 2019 г., что отмечается ростом во всех высокотехнологичных отраслях промышленности.

Наибольший прирост наблюдается в производстве компьютерной, электронной и оптической продукции - в 6 раз с 61,9 млрд. долл. США в 2004 г. до 364,2 млрд. долл. США в 2019 г. Однако несмотря на то, что Китай добился впечатляющего прогресса в своих суперкомпьютерных способностях за последние 10 лет, китайские полупроводниковые компании по-прежнему зависят от иностранных поставок комплектующих.

Китай является важной составной частью «Фабрики Азии» - системы производственно-сбытовых цепочек электронных товаров, сосредоточенной в Азиатско-Тихоокеанском регионе. Китай занимает ведущую роль в этой системе, как место финальной сборки электронной продукции и как крупнейший импортер и экспортер электронных компонентов, за счет развитых производственных мощностей, широкой сети поставщиков, большого количества квалифицированной рабочей силы и способности быстро наращивать производство, что требуется для производства электронной продукции, имеющей короткий цикл развития [7 С. 226].

Япония, Сингапур, Республика Корея являются одними из крупнейших производителей компонентов и готовых электронных изделий и находятся в тесной кооперации с Китаем. Эти три азиатские экономики являются основными импортерами электронных компонентов из Китая. Согласно данным ОЭСР по торговле добавленной стоимостью, Китай является важнейшим поставщиком компьютерной, электронной и оптической продукции в Японию, Республику Корея (более 30\% импорта этих стран), а также занимает 17\% импорта Сингапура. Одновременно Республика Корея является основным экспортером комплектующих этой отрасли промышленности в Китай. В свою очередь в 2015 г. объем импорта китайской компьютерной, электронной и оптической продукции составил $25 \%$ общего импорта Республики Корея [7 С. 240].

Китай также заметно увеличил свои позиции в производстве фармацевтической продукции (с 16,1 млрд. долл. США в 2004 г. до 162,5 млрд. долл. США в 2019 г.в 10 раз) и предоставлении научно-исследовательских услуг (с 7,7 млрд. долл. США в 2004 г. до 111,2 млрд. долл. США в 2019 г.— в 15 раз), став третьим по величине мировым производителем этих отраслей.

Быстро растущий уровень среднего класса, проводимые Китаем реформы системы здравоохранения и увеличивающийся спрос на медицинские услуги способствовали быстрому развитию фармацевтической промышленности Китая [8]. Многие транснациональные биофармацевтические компании создали научно-исследовательские центры в Китае для получения доступа к внутреннему рынку страны. Китайские компании в свою очередь продолжают расширять инвестиционные потоки в фармацевтическую отрасль промышленности [9]. В авиационной промышленности Китая последние 5 лет также наблюдался стремительный рост - на 64\% (с 10,3 млрд. долл. США в 2015 г. до 16,8 млрд. долл. США в 2019 г.).

Доля ЕС в создании добавленной стоимости мирового производства высокотехнологичных товаров и наукоемких услуг сократилась с 25,6\% в 2009 г. до $22 \%$ в 2012 г. и варьировалась в диапазоне 18-21\% с 2012 по 2019 гг. (Рисунок 4). ЕС является вторым по величине производителем авиационной техники (24,2\% мировой производства - 58,7 млрд. долл. США) и создателем программного обеспечения (23,9\% - 110,1 млрд. долл. США). В производстве компьютерной, электронной и оптической продукции доля ЕС в 2019 г. занимает значительно меньшую долю - 10,1\% (119,7 млрд. долл. США), чем в США и Китае.

Участие Японии создании добавленной стоимости мирового производства высокотехнологичных отраслей промышленности сократилось с 12,5\% в 2004 г. до 4,5\% в 2019 г. Наибольший спад наблюдался в производстве компьютерной, электронной и оптической продукции с 18\% (110,6 млрд. долл. США) до 6,2\% (74,0 млрд. долл. (ША) за аналогичный период. Снижение доля Японии в производстве высокотехнологичных отраслей промышленности является следствием снижения численности высококвалифицированных специалистов этих отраслей, а также переносом производственных мощностей в Китай и другие страны.

Объемы добавленной стоимости в производстве высокотехнологичных отраслей промышленности других стран Азии вырос в 3,2 раза с 87,7 млрд. долл. США 
Таблица 3. Объемы добавленной стоимости производства высокотехнологичных отраслей промышленности других стран Азии, 2004-2018 гг. (млрд. долл. США).

\begin{tabular}{|l|l|l|l|l|l|}
\hline Отрасли & $\mathbf{2 0 0 4}$ & $\mathbf{2 0 0 9}$ & $\mathbf{2 0 1 5}$ & $\mathbf{2 0 1 8}$ & $\mathbf{2 0 1 9}$ \\
\hline Программное обеспечение & 3,37 & 5,16 & 6,35 & 6,5 & 6,82 \\
\hline Научно-исследовательская деятельность & 9,7 & 22,7 & 47,1 & 55,9 & 59 \\
\hline Компьютерные, электронные и оптические изделия & 60,9 & 95,8 & 144,2 & 153,5 & 159,7 \\
\hline Фармацевтика & 11,4 & 22,1 & 29,5 & 40,1 & 45,7 \\
\hline Авиационная промышленность & 3,03 & 4,71 & 7,21 & 6,25 & 7,46 \\
\hline
\end{tabular}

Источник: рассчитано автором на основе [5].

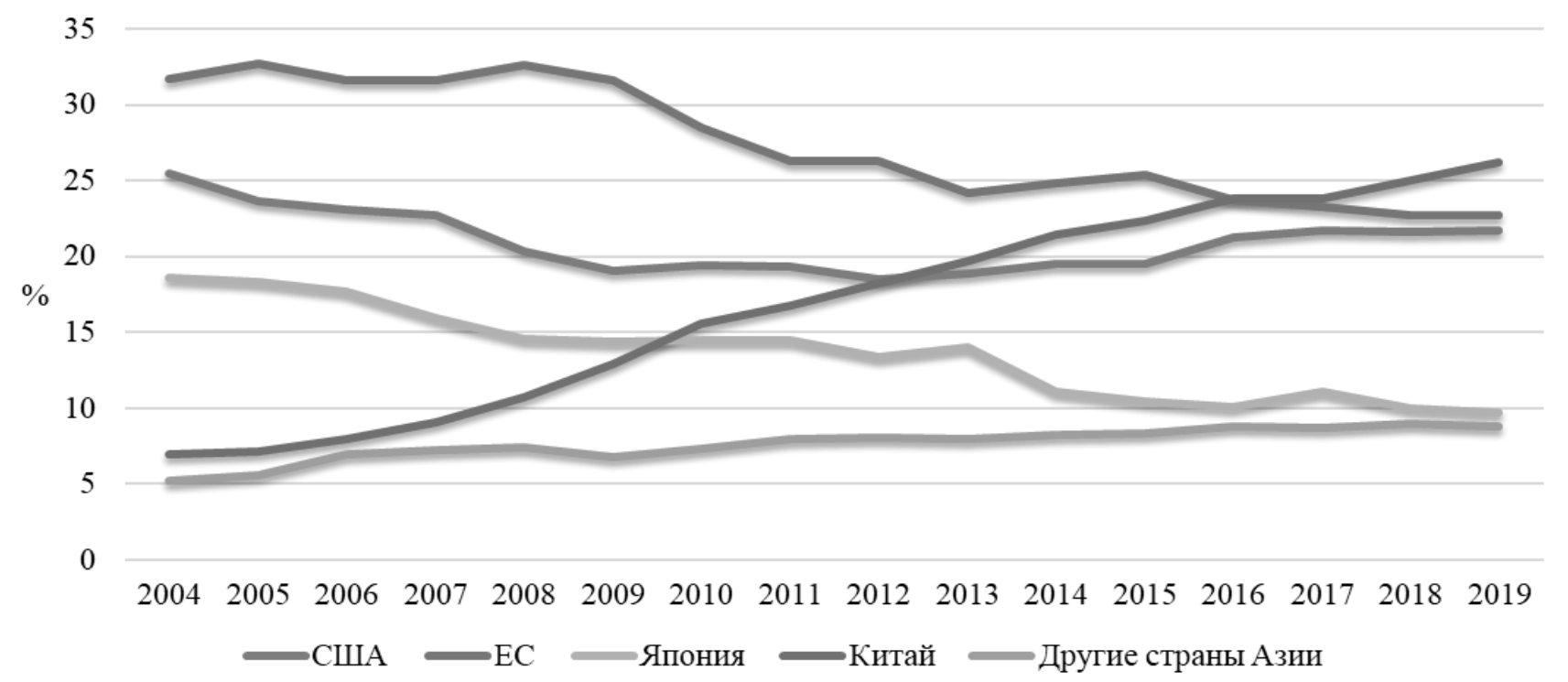

Рис. 5. Доля участия отдельных стран и регионов в создании добавленной стоимости производства продукции и услуг среднетехнологичных отраслей промышленности высокого уровня, 2004-2019 гг. (\%)

Источник: рассчитано автором на основе [5].

в 2004 г. до 280,1 млрд. долл. США. в 2019 г. Наибольший прирост наблюдается в производстве компьютерной, электронной и оптической продукции - в 2,6 раза с 60,9 млрд. долл. США в 2004 г. до 159,7 млрд. долл. США в 2019 г., а также в предоставлении научно-исследовательских услуг - рост в 6 раз с 9,7 млрд. долл. США в 2004 г. до 59 млрд. долл. США в 2019 г. (Таблица 3).

В среднетехнологичных отраслях промышленности высокого уровня наблюдается несколько иная ситуация.

С 2016 г. Китай является крупнейшим мировым производителем в этих отраслях, увеличивший свою долю в создании добавленной стоимости мирового объема производства с 7\% в 2004 г. до 26,2\% в 2019 г. (с 165,4 млрд. долл. США до 1,5 трлн. долл. США), за которым следуют ЕС и США - 22,7\% (1,3 трлн. долл. США) и 21,7\% (1,25 трлн. долл. США) соответственно (Рисунок 5).
Доля Японии в создании добавленной стоимости мирового производства среднетехнологичных отраслей промышленности высокого уровня сократилась практически в 2 раза с 18,6\% в 2004 г. до 9,6\% в 2019 г. мирового объема производства среднетехнологичных отраслей высокого уровня, однако стоимостные показатели продолжали расти (с 437,3 млрд. долл. США в 2004 г. до 557,6 млрд. долл. США в 2019 г.).

Доля других стран Азии в создании добавленной стоимости мирового производства среднетехнологичных отраслей промышленности высокого уровня после повышения в 2006 г. на протяжении последних лет сохраняет стабильные показатели с небольшим ежегодным приростом. В 2019 г. эта доля составила 9\% общего объема производства - 463,8 млрд. долл. США.

Среднетехнологичные отрасли промышленности высокого уровня также, как и высокотехнологичные отрас- 
Таблица 4. Доля участия отдельных стран и регионов в создании добавленной стоимости мирового производства среднетехнологичной промышленности высокого уровня в 2004 г. (\%)

\begin{tabular}{|c|c|c|c|c|c|c|}
\hline $\begin{array}{l}\text { Отрасли среднетехнологичной } \\
\text { промышленности высокого уровня }\end{array}$ & $\begin{array}{l}\text { Мировой объем } \\
\text { производства } \\
\text { (млрд. долл. США) }\end{array}$ & США & EC & Китай & Япония & $\begin{array}{l}\text { Другие } \\
\text { страны } \\
\text { Азии }\end{array}$ \\
\hline $\begin{array}{l}\text { Химические вещества, за исключением } \\
\text { фармацевтических препаратов }\end{array}$ & 428,4 & $25,8 \%$ & $28,4 \%$ & $10,1 \%$ & $12,2 \%$ & $6,2 \%$ \\
\hline Электротехническое оборудование & 268,7 & $16,9 \%$ & $32,2 \%$ & $11,8 \%$ & $22,7 \%$ & $5,6 \%$ \\
\hline ИТ-услуги & 554,3 & $33 \%$ & $34,3 \%$ & $1,46 \%$ & $17,9 \%$ & $3,7 \%$ \\
\hline Машины и оборудование & 496,3 & $21,2 \%$ & $34,4 \%$ & $8,2 \%$ & $22,2 \%$ & $4,1 \%$ \\
\hline Автомобильный транспорт & 546,5 & $26,2 \%$ & $29,4 \%$ & $6,3 \%$ & $20 \%$ & $5,8 \%$ \\
\hline Ж/Д и др. транспорт & 42,4 & $23,8 \%$ & $25 \%$ & $13,9 \%$ & $9,4 \%$ & $13,1 \%$ \\
\hline Оружие & 18,2 & $14,8 \%$ & $30,2 \%$ & $2,19 \%$ & $2,74 \%$ & $5,63 \%$ \\
\hline
\end{tabular}

Источник: рассчитано автором на основе [5].

Таблица 5. Доля участия отдельных стран и регионов в создании добавленной стоимости мирового производства среднетехнологичной промышленности высокого уровня в 2019 г. (\%)

\begin{tabular}{|c|c|c|c|c|c|c|}
\hline $\begin{array}{l}\text { Отрасли } \\
\text { среднетехнологичной } \\
\text { промышленности высокого } \\
\text { уровня }\end{array}$ & $\begin{array}{l}\text { Мировой объем } \\
\text { производства } \\
\text { (млрд. долл. США) }\end{array}$ & США & EC & Китай & Япония & $\begin{array}{l}\text { Другие } \\
\text { страны Азии }\end{array}$ \\
\hline $\begin{array}{l}\text { Химические вещества, } \\
\text { за исключением } \\
\text { фармацевтических препаратов }\end{array}$ & 1026,4 & $21,1 \%$ & $17,0 \%$ & $29,1 \%$ & $5,6 \%$ & $8,9 \%$ \\
\hline $\begin{array}{l}\text { Электротехническое } \\
\text { оборудование }\end{array}$ & 655,7 & $9,4 \%$ & $17,6 \%$ & $46,2 \%$ & $10,2 \%$ & $7,5 \%$ \\
\hline ИТ-услуги & 1621,8 & $36,9 \%$ & $26,6 \%$ & $10,1 \%$ & $7,5 \%$ & $8 \%$ \\
\hline Машины и оборудование & 1195,2 & $15,0 \%$ & $24,2 \%$ & $33,3 \%$ & $13,5 \%$ & $5,7 \%$ \\
\hline Автомобильный транспорт & 1109,7 & $15,2 \%$ & $24,4 \%$ & $27,2 \%$ & $13,0 \%$ & $9,6 \%$ \\
\hline Ж/Д и др. транспорт & 119,9 & $15,0 \%$ & $15,3 \%$ & $37,0 \%$ & $4,2 \%$ & $12 \%$ \\
\hline Оружие & 50,1 & $18,2 \%$ & $21,0 \%$ & $10,1 \%$ & $1,4 \%$ & $9 \%$ \\
\hline
\end{tabular}

Источник: рассчитано автором на основе [5].

ли промышленности имеют сложные ГЦДС, и, как правило, располагаются в близи рынков сбыта. Транспортные издержки занимают значительную часть конечной стоимости продукции этих отраслей, в виду своих больших физических размеров и показателей массы (например, автомобили, крупная бытовая и спецтехника).

США являются крупнейшим в мире производителем ИТ-услуг, с долей чуть менее $40 \%$ добавленной стоимости мирового производства этой отрасли $(598,1$ млрд. долл. США). Стоит отметить что это единственная отрасль среднетехнологичной промышленности высокого уровня, где США еще удается удерживать лидирующую позицию в течение последних 15 лет. Производство химических веществ, за исключением фармацевтических препаратов составляет 21,1\% мирового объема (216,7 млрд. долл. США), железнодорожный и другой транспорт - 15\% (17,9 млрд. долл. США) (Таблица 4, Таблица 5).
По состоянию на 2019 г. Китай является крупнейшим в мире производителем химических веществ, за исключением фармацевтических препаратов - 29,1\% мировой добавленной стоимости производства среднетехнологичной промышленности высокого уровня; электротехнического оборудования - 46,2\%; автотранспортных средств - 27,2\%, машин и оборудования 33,3\%, а также железнодорожного и другого транспорта - 37\%. Эти отрасли промышленности развивались в течение двух последних десятилетий стремительными темпами.

Добавленная стоимость мирового объема производства электротехнического оборудования выросла в три раза с 268,7 млрд. долл. США в 2004 г. до 655 млрд. долл. США в 2019 г., при этом доля Китая в мировом производстве этой отрасли увеличилась почтив 10 раз за аналогичный период (с 31,8 млрд. долл. США до 302,9 млрд. долл. США). 
Таблица 6. Место стран и регионов в формировании добавленной стоимости высокотехнологичных отраслей промышленности и среднетехнологичных отраслей промышленности высокого уровня.

\begin{tabular}{|c|c|c|c|c|c|c|c|c|c|c|}
\hline \multirow{2}{*}{ Отрасль } & \multicolumn{2}{|l|}{ США } & \multicolumn{2}{|l|}{ EC } & \multicolumn{2}{|c|}{ Япония } & \multicolumn{2}{|c|}{ Китай } & \multicolumn{2}{|c|}{ Другие страны Азии } \\
\hline & 2004 & 2019 & 2004 & 2019 & 2004 & 2019 & 2004 & 2019 & 2004 & 2019 \\
\hline \multicolumn{11}{|c|}{ Высокотехнологичные отрасли промышленности } \\
\hline Программное обеспечение & 1 & 1 & 2 & 2 & 3 & 4 & 5 & 3 & 4 & 5 \\
\hline $\begin{array}{l}\text { Научно-исследовательская } \\
\text { деятельность }\end{array}$ & 1 & 1 & 2 & 2 & 3 & 5 & 5 & 3 & 4 & 4 \\
\hline $\begin{array}{l}\text { Компьютерные, электронные } \\
\text { и оптические изделия }\end{array}$ & 1 & 2 & 3 & 4 & 2 & 5 & 5 & 1 & 4 & 3 \\
\hline Фармацевтика & 1 & 1 & 2 & 2 & 3 & 5 & 4 & 3 & 5 & 4 \\
\hline $\begin{array}{l}\text { Авиационная } \\
\text { промышленность }\end{array}$ & 1 & 1 & 2 & 2 & 5 & 5 & 4 & 3 & 3 & 4 \\
\hline \multicolumn{11}{|c|}{ Среднетехнологичные отрасли промышленности высокого уровня } \\
\hline $\begin{array}{l}\text { Химические вещества, } \\
\text { за исключением } \\
\text { фармацевтических } \\
\text { препаратов }\end{array}$ & 1 & 2 & 2 & 3 & 3 & 5 & 4 & 1 & 5 & 4 \\
\hline $\begin{array}{l}\text { Электротехническое } \\
\text { оборудование }\end{array}$ & 3 & 4 & 1 & 2 & 2 & 3 & 4 & 1 & 5 & 5 \\
\hline ИТ-услуги & 1 & 1 & 2 & 2 & 3 & 5 & 5 & 3 & 4 & 4 \\
\hline Машины и оборудование & 2 & 3 & 1 & 2 & 3 & 4 & 4 & 1 & 5 & 5 \\
\hline Автомобильный транспорт & 1 & 3 & 2 & 2 & 3 & 4 & 4 & 1 & 5 & 5 \\
\hline Ж/Д и др. транспорт & 1 & 3 & 2 & 2 & 5 & 5 & 3 & 1 & 4 & 4 \\
\hline Оружие & 2 & 2 & 1 & 1 & 5 & 5 & 4 & 3 & 3 & 4 \\
\hline
\end{tabular}

Примечание: ранжирование от 1 до 5 (от большего объема в производстве, к меньшему).

Источник: составлено автором.

Производство машин и оборудования также увеличилось в 3 раза с 496,3 млрд. долл. США в 2004 г. до 1,19 трлн. долл. США в 2019 г. Доля Китая в мировом производстве этой отрасли также выросла в 5 раз до 33,3\% в 2019 году в сравнении с показателями 2004 г. (с 40,4 млрд. долл. США до 397,6 млрд. долл. США).

Мировое производство автомобильной промышленности выросло в 2,3 раза и составило 1,1 трлн. долл. США в 2019 г. против 546,5 млрд. долл. США в 2004 г.

Китай сумел превзойти ЕС по объемам производства этой отрасли и, начиная с 2018 г., стал крупнейшим в мире производителем автомобилей, заняв почти 30\% мирового производства (с 34,4 млрд. долл. США в 2004 г. до 302 млрд. долл. США в 2019 г.).

Объем добавленной стоимости ЕС в мировом производстве среднетехнологичных отраслей промышленности высокого уровня начал снижаться в период с 2008 г. с $33 \%$ и в 2019 г. составил $23 \%$, в основном за счет роста доли китайской продукции.

ЕС является вторым по величине производителем автотранспортных средств и ИТ-услуг с долей в миро- вом производстве $24 \%$ и $27 \%$ соответственно, уступая лишь Китаю и США.

Япония является четвертым крупнейшим производителем автотранспортных средств с долей мирового производства 13\%, но, к сожалению, утратила свое лидерство по всем остальным отраслевым группам.

Добавленная стоимость мирового объема производства среднетехнологичных отраслей высокого уровня других стран Азии в 2019 г. достигла значительных показателей - 8\% мирового объема, в частности в таких отраслях как химические вещества, за исключением фармацевтических препаратов - 8,9\% (92 млрд. долл. (ША), железнодорожного и другого транспорта - 12\% (14,3 млрд. долл. США), автотранспортных средств - 9,6\% (106,1 млрд. долл. США), ИТ-услуг 7,8\% (127,5 млрд. долл. США).

Таким образом, на сегодняшний день мировыми лидерами в производстве высокотехнологичных товаров и наукоемких услуг являются: США, ЕС, Китай, Япония и группа других стран Азии, представленная Республикой Кореей, Республикой Индией, Республикой Индонезией, Малайзией, Республикой Филиппины, 
Республикой Сингапур, Королевством Таиланд и Социалистической Республикой Вьетнам.

«Расстановку сил» на рынке мирового производства технологической продукции для наглядности мы представили в табличной форме (Таблица 6).

США и ЕС продолжают занимать лидирующие позиции во всех высокотехнологичных отраслях промышленности, за исключением отрасли по производству компьютерной, электронной и оптической продукции, где на первое место вышел Китай, который, в том числе, значительно улучшил свои позиции во всех высокотехнологичных отраслях промышленности.

Другие страны Азии (Республика Корея, Республика Индия, Республика Индонезия, Малайзия, Республика Филиппины, Республика Сингапур, Королевство Таиланд и Социалистическая Республика Вьетнам) смогли усилить позиции как в отрасли по производству компьютерной, электронной и опти- ческой продукции, так и в фармацевтической отрасли и продолжают поступательно наращивать объемы производства продукции высокотехнологичных отраслей промышленности.

Все данные изменения в негативном ключе затронули Японию, которая утратила свои позиции в производстве высокотехнологичной продукции.

Лидером в производстве продукции среднетехнологичных отраслей промышленности высокого уровня является Китай, за исключением таких сфер, как производство оружия и предоставление ИТ-услуг, где все также сильны позиции США и ЕС. Другие страны Азии смогли добиться определенных успехов в химической промышленности.

В среднетехнологичных отраслях промышленности высокого уровня Япония также продолжает терять долю в производстве под натиском Китая и других стран Азии.

\section{ЛИТЕРАТУРА}

1. OECD. The Development of Indicators to Measure the Output of R\&D: Some Preliminary Results and Plan for Future Work, STP (79), 1979.

2. OECD (2011). OECD Guide to Measuring the Information Society 2011. OECD Publishing.

3. Department of Economic and Social Affairs Statistics Division. United Nations Publication. Standard International Trade Classification Revision 4.

4. Galindo-Rueda F, Verger F. 2016. OECD Taxonomy of Economic Activities Based on R\&D Intensity. OECD Science, Technology and Industry Working Papers 2016/04. OECD Publishing, Paris. - p.10.

5. Электронная база данных IHS Markit [Электронный ресурc].— URL: https://ihsmarkit.com/products/data-lake.html

6. Электронная база данных Knoema [Электронный ресурc].— URL: https://knoema.ru/atlas/topics/BBП

7. M. Ohara et al. (eds. Industrial Dynamics in China and India: Firms, Clusters, and Different Growth Paths (2011, Hardcover) Institute of Developing Economies (IDE), JETRO 2011.

8. Yuanzhe Cao, Liujuan Zhu, Yanhua Shi — Performance Comparison of Rod-baffle and Segment-baffle Heat Exchangers Using Numerical Simulations [Электронный ресурc].— URL: https://ru.scribd.com/document/368960559/Са0-2014

9. Chen Zhao, Jianqing Xu — Toward universal influenza virus vaccines: from natural infection to vaccination strategy [Электронный ресурс]. — URL: https:// doi.org/10.1016/j.coi.2018.03.020

(с Гурков Родион Александрович ( gurkov_rodion@mail.ru ). 